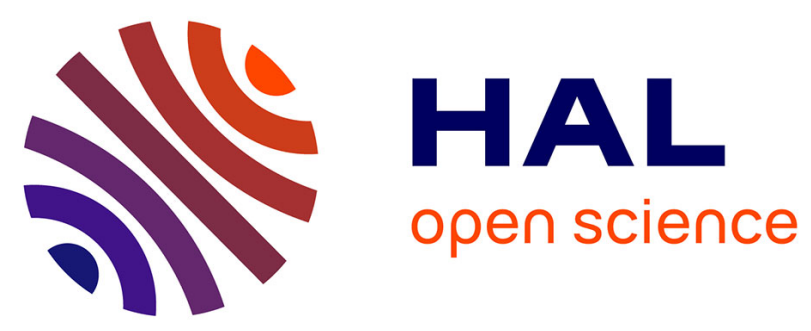

\title{
Carboxylate anion generation in aqueous solution from carbonate radiolysis, a potential route for abiotic organic acid synthesis on Earth and beyond
}

Johan Vandenborre, Laurent Truche, Amaury Costagliola, Emeline Craff, Guillaume Blain, Véronique Baty, Ferid Haddad, Massoud Fattahi

\section{To cite this version:}

Johan Vandenborre, Laurent Truche, Amaury Costagliola, Emeline Craff, Guillaume Blain, et al.. Carboxylate anion generation in aqueous solution from carbonate radiolysis, a potential route for abiotic organic acid synthesis on Earth and beyond. Earth and Planetary Science Letters, 2021, 564, pp.116892. 10.1016/j.epsl.2021.116892 . in2p3-03190340

\section{HAL Id: in2p3-03190340 \\ https://hal.in2p3.fr/in2p3-03190340}

Submitted on 6 Oct 2021

HAL is a multi-disciplinary open access archive for the deposit and dissemination of scientific research documents, whether they are published or not. The documents may come from teaching and research institutions in France or abroad, or from public or private research centers.
L'archive ouverte pluridisciplinaire HAL, est destinée au dépôt et à la diffusion de documents scientifiques de niveau recherche, publiés ou non, émanant des établissements d'enseignement et de recherche français ou étrangers, des laboratoires publics ou privés. 


\section{Carboxylate anion generation in aqueous solution}

2

11 ABSTRACT:

12 Low molecular weight carboxylate anions such as formate $\left(\mathrm{HCOO}^{-}\right)$, acetate $\left(\mathrm{CH}_{3} \mathrm{COO}^{-}\right)$and 13 oxalate $\left(\mathrm{C}_{2} \mathrm{O}_{4}{ }^{2-}\right)$ have been shown to play an important role in supporting deep subsurface 14 microbial ecosystems. Their origin whether biological or abiotic is currently highly debated, but 15 surprisingly radiolytic production has rarely been considered, as it is the case for $\mathrm{H}_{2}$. Here, we 16 address this question through dedicated irradiation experiments. Aqueous solutions containing 17 carbonate, formate, acetate or oxalate have been irradiated using both the $60.7 \mathrm{MeV} \alpha$-beam of 18 the ARRONAX cyclotron (Nantes, France) and $661.7 \mathrm{keV} \gamma$-Ray in order to reveal the 19 mechanism and chemical yield of radiation-induced dissolved carbonate degradation.

\footnotetext{
* Corresponding Author. Email Address : Johan.Vandenborre@subatech.in2p3.fr
} 
20 The yields (G-values) of carboxylate anions production/degradation in low-concentration

21 carbonate solution ( 0.01 to $\left.1 \mathrm{mmol} \mathrm{L}^{-1}\right)$ are measured. Carbonate degradation occurs through

22 three consecutive steps (Carbonate $\stackrel{I}{\rightarrow}$ Formate $\stackrel{I I}{\rightarrow}$ Acetate $\stackrel{I I I}{\rightarrow}$ Oxalate) involving formate radical

$23\left(\mathrm{CO}_{2}^{-*}\right)$, dihydrogen $\left(\mathrm{H}_{2}\right)$, and carbon dioxide $\left(\mathrm{CO}_{2}\right)$ generation. Dissolved carbonate radiolysis

24 provides a consistent pathway for both enhancing two-fold the radiolytic $\mathrm{H}_{2}$ production

25 compared to pure water and generating carboxylic species, chiefly oxalate, readily available for

26 microbes. Radiation-induced carbonate degradation may produce substantial amount (millimolar

27 concentration) of carboxylate anions in ancient groundwaters from deep crystalline bedrocks.

28 Subsurface lithoautotrophic microbial ecosystems may not only be supported by radiolytic $\mathrm{H}_{2}$

29 but also by carboxylate species from carbonate radiolysis. Carbonate radiolysis can be also an

30 endogenous source of carboxylate species on Mars and other planetary bodies.

\section{Introduction}

33 Abiotic organic synthesis is central to life emergence, deep subsurface microbial activity, and 34 global geochemical carbon cycling (Ménez 2020, Truche et al. 2020). Currently, there are two 35 major sources of abiotic organic compounds envisioned on Earth. First, they could be mantle 36 sourced and supplied to the crust through the migration of magmatic fluids (Sephton and Hazen

37 2013). Second, they could be formed within the crust through reduction of inorganic carbon 38 compounds such as carbonates or $\mathrm{CO}$. This latter process is supposed to be triggered by water39 rock reactions involving molecular hydrogen $\left(\mathrm{H}_{2}\right)$ and catalyst surfaces (McCollom 2013, 40 Seewald 2001). Molecular hydrogen may be produced abiotically by the reduction of water in 41 the presence of $\mathrm{Fe}(\mathrm{II})$-bearing minerals, by reaction of $\mathrm{FeS}$ (pyrrhotite) with water to generate $42 \mathrm{FeS}_{2}$ (pyrite) plus $\mathrm{H}_{2}$, or even by the reaction of water with surface radicals during mechanical 
43 fracturing of silicate-bearing rocks (Klein et al. 2020). Water radiolysis due to radioactive decay

44 either by $\alpha$-emitters such as $\mathrm{U}$ and $\mathrm{Th}$ or $\gamma$-Ray emitter such as $\mathrm{K}^{40}$ is also considered as an

45 important source of $\mathrm{H}_{2}$ in the Earth's crust (Lin et al. 2005, Sherwood Lollar et al. 2014).

46 Among the abiotic organic compounds potentially produced at depth, the low molecular weight

47 organic acids, such as formate and acetate, have attracted particular attention as they have been

48 shown to play an important role in supporting deep microbial communities, either in serpentinite-

49 hosted environments (Fones et al. 2019, Lang et al. 2018) or in deep crystalline bedrocks

50 (Bomberg et al. 2016, Hoehler and Jørgensen 2013, Purkamo et al. 2017). Even if the abiotic

51 nature of their sources is still a matter of intense debate, the rational for carboxylate anions

52 formation during carbonates radiolysis in aqueous solution remains currently ignored in these

53 natural and undisturbed geological settings (Sherwood Lollar et al. 2021). A radiation-induced

54 source of carboxylate anions would be particularly relevant in Precambrian Shield environments

55 because of the high dose deposited in deep fracture fluids, which results from both the long

56 residence time of groundwaters and the radioactive decay of $\mathrm{U}$, Th, and $\mathrm{K}$ enriched within the

57 rock matrix (Holland et al. 2013, Warr et al. 2019).

58 Carboxylate anions (formate $\mathrm{HCOO}^{-}$, oxalate $\mathrm{C}_{2} \mathrm{O}_{4}{ }^{2-}$, glyoxylate $(\mathrm{HO})_{2} \mathrm{CHCO}_{2}^{-}$, glycolate

$59 \mathrm{C}_{2} \mathrm{H}_{3} \mathrm{O}_{3}{ }^{-}$and acetate $\mathrm{CH}_{3} \mathrm{COO}^{-}$) are the main organic products during carbonate-bearing aqueous

60 solutions radiolysis (Cai et al. 2001, Costagliola et al. 2017, Draganić et al. 1991). Although the

61 radiation chemistry of carbonate-bearing solutions has been extensively studied within the

62 framework of nuclear waste geological disposal, there is a still major uncertainty regarding: i)

63 the reaction mechanisms, ii) the respective yield of each carboxylate species, and iii) the Linear

64 Energy Transfer (LET) effect (i.e. the amount of energy that an ionizing particle transfers to the

65 material traversed - here water - per distance unit). A detailed understanding of the mechanism 
66 and yield of radiolytic carboxylates production is necessary to constrain their concentrations in

67 natural groundwaters and assess their importance as carbon sources for the deep subsurface

68 biosphere.

69 To fill this gap, we studied the behavior of radiolytic carbonate degradation products as a 70 function of the dose deposited into low-concentration carbonate aqueous solutions (0.01 to 1

$71 \mathrm{mmol} \mathrm{L}{ }^{-1}$ ) representative of ancient groundwaters from deep crystalline bedrocks (Bomberg et al.

72 2016, Kieft et al. 2018, Pedersen and Ekendahl 1992, Sherwood Lollar et al. 2021). We

73 quantified the production/degradation of each species: carbonate $\left(\mathrm{CO}_{2} / \mathrm{HCO}_{3}{ }^{-} / \mathrm{CO}_{3}{ }^{2-}\right)$, molecular

74 hydrogen $\left(\mathrm{H}_{2}\right)$, formate $\left(\mathrm{HCOO}^{-}\right)$, acetate $\left(\mathrm{CH}_{3} \mathrm{COO}^{-}\right)$and oxalate $\left(\mathrm{C}_{2} \mathrm{O}_{4}{ }^{2-}\right)$ ions. In addition, we

75 investigated for the first time the LET effect by comparing $\gamma$-Ray experiments with newly 76 performed high energy helium ion $\left(\mathrm{He}^{2+}=\alpha\right.$-beam irradiation $)$ ones. The measured carboxylates

77 production yields were used to calculate their long-term production in natural settings and 78 discuss their potential role in supporting deep microbial ecosystems.

\section{Carbonate radiolysis and recombination of radical species}

81 During the irradiation of carbonate solutions, water radiolysis byproducts $\left(\mathrm{e}_{\mathrm{aq}}^{-}=\right.$aqueous 82 electron with water coordination $\left(\mathrm{H}^{\bullet}, \mathrm{HO}^{\bullet}, \mathrm{H}_{2}, \mathrm{H}_{2} \mathrm{O}_{2}, \mathrm{H}_{3} \mathrm{O}^{+}\right)$react with $\mathrm{CO}_{2}, \mathrm{CO}_{3}{ }^{2-}$ and $\mathrm{HCO}_{3}^{-}$

83 and produce $\mathrm{CO}_{2}^{-\bullet}$ and $\mathrm{CO}_{3}^{-\bullet}$ radicals according to:

$$
\begin{aligned}
& \mathrm{CO}_{2}+\mathrm{e}_{\mathrm{aq}}^{-} \rightarrow \mathrm{CO}_{2}^{-\bullet} ; \mathrm{k}_{1}=7.7 \times 10^{9} \mathrm{~L} \mathrm{~mol}^{-1} \mathrm{~s}^{-1} \\
& \mathrm{CO}_{3}{ }^{2-}+\mathrm{e}_{\mathrm{aq}}{ }^{-} \rightarrow \mathrm{CO}_{2}^{-\bullet}+2 \mathrm{OH}^{-} ; \mathrm{k}_{2}=3.9 \times 10^{5} \mathrm{~L} \mathrm{~mol}^{-1} \mathrm{~s}^{-1} \\
& \mathrm{CO}_{3}{ }^{2-}+\mathrm{HO}^{\cdot} \rightarrow \mathrm{CO}_{3}^{-\bullet}+\mathrm{OH}^{-} ; \mathrm{k}_{3}=3.9 \times 10^{8} \mathrm{~L} \mathrm{~mol}^{-1} \mathrm{~s}^{-1} \\
& \mathrm{HCO}_{3}{ }^{-}+\mathrm{H}^{-} \rightarrow \mathrm{CO}_{3}^{-\bullet}+\mathrm{H}_{2} ; \mathrm{k}_{4}=4.4 \times 10^{4} \mathrm{~L} \mathrm{~mol}^{-1} \mathrm{~s}^{-1} \\
& \mathrm{HCO}_{3}{ }^{-}+\mathrm{HO}^{-} \rightarrow \mathrm{CO}_{3}^{-\cdot}+\mathrm{H}_{2} \mathrm{O} ; \mathrm{k}_{5}=8.5 \times 10^{6} \mathrm{~L} \mathrm{~mol}^{-1} \mathrm{~s}^{-1}
\end{aligned}
$$

84 Where $\mathrm{k}$ is the rate constant of the reaction in $\mathrm{L} \mathrm{mol}^{-1} \mathrm{~s}^{-1}$. 
85 These radicals mainly recombine with each other or react with other radical species produced by

86 water radiolysis. The following reactions lead to the formation of carboxylate ions such as

87 oxalate and formate :

$$
\begin{aligned}
& \mathrm{CO}_{2}{ }^{-}+\mathrm{CO}_{2}{ }^{-} \rightarrow \mathrm{C}_{2} \mathrm{O}_{4}{ }^{2-} ; \mathrm{k}_{6}=5.0 \times 10^{8} \mathrm{~L} \mathrm{~mol}^{-1} \mathrm{~s}^{-1} \\
& \mathrm{CO}_{3}{ }^{-}+\mathrm{CO}_{2}^{-} \rightarrow \mathrm{CO}_{3}{ }^{2-}+\mathrm{CO}_{2} ; \mathrm{k}_{7}=3.0 \times 10^{8} \mathrm{~L} \mathrm{~mol}^{-1} \mathrm{~s}^{-1} \\
& \mathrm{CO}_{2}{ }^{-}+\mathrm{e}_{\mathrm{aq}} \rightarrow \mathrm{HCOO}+\mathrm{OH}^{-} ; \mathrm{k}_{8}=9.0 \times 10^{8} \mathrm{~L} \mathrm{~mol}^{-1} \mathrm{~s}^{-1}
\end{aligned}
$$

88 The radiation chemical behavior of formate has already been the subject of several studies

89 (Albarrán et al. 1987, 1994, Cai et al. 2001, Costagliola et al. 2017, Draganić et al. 1991). The

90 main formate (or formic acid) degradation reaction by water radiolysis products are the

91 following:

$$
\begin{aligned}
& \mathrm{HCOOH}+\mathrm{OH}^{\cdot} \rightarrow \mathrm{COOH}^{-}+\mathrm{H}_{2} \mathrm{O} ; \mathrm{k}_{9}=1.4 \times 10^{8} \mathrm{~L} \mathrm{~mol}^{-1} \mathrm{~s}^{-1} \\
& \mathrm{HCOO}^{-}+\mathrm{OH}^{-} \rightarrow \mathrm{CO}_{2}^{-}+\mathrm{H}_{2} \mathrm{O} ; \mathrm{k}_{10}=3.2 \times 10^{9} \mathrm{~L} \mathrm{~mol}^{-1} \mathrm{~s}^{-1} \\
& \mathrm{HCOO}^{-}+\mathrm{H}^{-} \rightarrow \mathrm{CO}_{2}^{-}+\mathrm{H}_{2} ; \mathrm{k}_{11}=2.1 \times 10^{8} \mathrm{~L} \mathrm{~mol}^{-1} \mathrm{~s}^{-1} \\
& \mathrm{HCOO}^{-}+\mathrm{e}_{\mathrm{aq}}{ }^{-}+\mathrm{H}^{+} \rightarrow \mathrm{CO}_{2}^{-}+\mathrm{H}_{2} ; \mathrm{k}_{12}=8.0 \times 10^{8} \mathrm{~L} \mathrm{~mol}^{-1} \mathrm{~s}^{-1} \\
& \mathrm{HCOO}^{-}+\mathrm{CO}_{3}^{-} \rightarrow \mathrm{CO}_{2}^{-}+\mathrm{HCO}_{3}^{-} ; \mathrm{k}_{13}=10^{5} \mathrm{~L} \mathrm{~mol}^{-1} \mathrm{~s}^{-1}
\end{aligned}
$$

92 Recently, we have discussed the impact of ionizing radiations ( $\alpha$-beam and $\gamma$-Ray) on calcite and

93 calcium carbonate solutions (Costagliola et al. 2017). We have shown that calcite dissolution is

94 accompanied by organic anions formation such as formate, acetate and oxalate ions. However,

95 whereas the formate and oxalate ions production has been previously described in the literature,

96 (Draganić et al. 1991), the acetate production mechanism remains not well-understood.

97 Moreover, for these carboxylate anions, no unquestionable quantification was proposed for their

98 production/degradation radiolytic yield. Albarrán et al. 1987, 1994 have observed acetate

99 formation following $\gamma$-Ray of calcite, but without clear explanation. Cai et al. 2001 have

100 accurately determined the chemical yield of oxalate $\left(\mathrm{G}_{\gamma}\left(\mathrm{C}_{2} \mathrm{O}_{4}{ }^{2-}\right)=2 \mathrm{nmol} \mathrm{\textrm {J } ^ { - 1 }}\right)$ at high

101 concentration of bicarbonate $\left(50 \mathrm{mmol} \mathrm{L}^{-1}\right)$ in aqueous solution, but without acetate and formate 
102 quantification. Here, we perform a complete measurement and quantification of the carboxylate

103 ions behavior during dissolved carbonate radiolytic degradation under both $\alpha$-beam and $\gamma$-Ray.

104

\section{Experimental methods}

\subsection{Sample sets and analytical procedures}

107 All the aqueous solution used in the experiments were prepared with commercial chemical 108 products as received with no further purification. All reactants were analytical grade and the 109 aqueous samples were prepared with ultrapure (MilliQ) water. A summary of each experiment

110 with the values of parameters used is given in Table 1. All the experiments have been carried out

111 at $21 \pm 1^{\circ} \mathrm{C}$. Carboxylate-bearing experiments were performed under aerated condition and

112 initial $\mathrm{pH}=7.0$. At such a $\mathrm{pH}$ value, the carboxylate anions predominate in solution. Carbonate-

113 bearing experiments were performed under $\mathrm{Ar}$ atmosphere and initial $\mathrm{pH}=10$ to avoid $\mathrm{CO}_{2}$

114 degassing. In the present case, the atmosphere composition (air vs. Ar) has no significant impact

115 on the mass balance of the reaction as described by Costagliola et al. 2017. Dissolved

116 concentrations of carboxylate and carbonate anions fall within a representative range of natural

117 groundwater $\left(0.01\right.$ to $\left.1 \mathrm{mmol} \mathrm{L}^{-1}\right)$.

118 Molecular hydrogen $\left(\mathrm{H}_{2}\right)$ and carbon dioxide $\left(\mathrm{CO}_{2}\right)$ have been monitored by micro gas119 chromatography $(\mu \mathrm{GC})$ using a 490-GC (VARIAN $\left.{ }^{\circledR}\right)$ micro gas-chromatograph. Two columns

120 were used: a $5 \AA$ molecular sieve for $\mathrm{H}_{2}$ and a poraplot $\mathrm{Q}$ for $\mathrm{CO}_{2}$. The injection system and the

121 column were purged with argon beforehand. Carboxylate anions concentration was determined

122 by ionic chromatography using a METROHM 850 pro IC chromatograph with a Metrosep

123 ASUP16 column. This column was thermostated at $55^{\circ} \mathrm{C}$ and a 75 mmol $\mathrm{L}^{-1} \mathrm{Na}_{2} \mathrm{CO}_{3}+0.75$

124 mmol L ${ }^{-1} \mathrm{NaOH}$ eluent was chosen. Finally, carbonate anions concentration was determined 
125 using a DIONEX ${ }^{\circledR}$ chromatograph with a DIONEX ${ }^{\circledR}$ IonPac AS18 column and 0.25 mmol L ${ }^{-1}$

$126 \mathrm{NaOH}$ eluent. All our chromatographic measurements (both IC and GC) were repeated 3 times,

127 with a precision of $3 \%$ at the $95 \%$ confidence level. All the analytical results are reported in 128 supplementary Table S1.

130 Table 1. Summary of experimental conditions used in this work

\begin{tabular}{|c|c|c|c|c|c|}
\hline \#Sample Name & Initial Solution & $\begin{array}{l}\text { Initial Conc. } \\
\text { mmol L }^{-1}\end{array}$ & Radiation & $\begin{array}{l}\text { Total Dose } \\
(\mathrm{Gy})\end{array}$ & $\begin{array}{l}\text { Irradiation } \\
\text { Time (min) }\end{array}$ \\
\hline He-Carb & Carbonate & 0.2 & $\alpha$-beam & 5600 & 8 \\
\hline G-Water & MilliQ water & - & $\gamma$-Ray & 1434 & 180 \\
\hline G-Form & Formate & 0.01 & $\gamma$-Ray & 1900 & 240 \\
\hline G-Ac & Acetate & 0.01 & $\gamma$-Ray & 1780 & 220 \\
\hline G-Ox & Oxalate & 0.01 & $\gamma$-Ray & 1900 & 240 \\
\hline He-High-Form & Formate & 1 & $\alpha$-beam & 10500 & 15 \\
\hline He-Low-Form & Formate & 0.01 & $\alpha$-beam & 10500 & 15 \\
\hline He-High-Ac & Acetate & 1 & $\alpha$-beam & 10500 & 15 \\
\hline He-Low-Ac & Acetate & 0.01 & $\alpha$-beam & 10500 & 15 \\
\hline He-High-Ox & Oxalate & 1 & $\alpha$-beam & 10500 & 15 \\
\hline He-Low-Ox & Oxalate & 0.01 & $\alpha$-beam & 10500 & 15 \\
\hline
\end{tabular}

\subsection{Irradiation experiments}

$133 \gamma$-Ray and $\alpha$-beam irradiations experiments were performed at the ARRONAX cyclotron (Nantes

134 - France) facility. The irradiation cells were made of PEEK (polyether ether ketone), mounted 135 with a rotulex $19 / 9$ glass tube and had an internal volume of $41 \mathrm{~mL}$ or $42 \mathrm{~mL}$ for $\alpha$ and $\gamma$ cells, 
136 respectively. These cells were gas-tightened using a screwed silicone seal joint in a glass-

137 metallic valve. The specificity of each experiment is discussed thereafter.

\subsection{1. $\alpha$-beam irradiation}

139 The initial energy of the ARRONAX $\alpha$-beam was $68 \mathrm{MeV}$. The PEEK irradiation cell was 140 equipped with a $150 \pm 15 \mu \mathrm{m}$ thick borosilicate glass disk as entrance window in order to

141 minimize energy losses as ions enter the cell. The SRIM2008 simulation code developped by 142 Ziegler et al. 2010 demonstrated that the particle energy on the other side of the entrance window 143 is $60.7 \pm 0.3 \mathrm{MeV}$. $20 \mathrm{~mL}$ of solutions at the desired concentration were loaded inside the cell.

144 Stirring of the solution was performed to ensure a homogenous irradiation of the medium.

145 Fricke dosimetry (Fricke and Hart 1966) was performed by in situ monitoring of the ferric ion 146 concentration with CARY-4000 (VARIAN ${ }^{\circledR}$ ) spectrophotometer, coupled to a $20 \mathrm{~m}$ long fiber 147 optics and a $10 \mathrm{~mm}$ optical path HELLMA ${ }^{\circledR}$ probe. This setup is described in supplementary 148 Figure S1. Therefore, the ferric ion radiolytic yield used for this $\alpha$-beam was $\mathrm{G}_{\alpha}\left(\mathrm{Fe}^{3+}\right)=1.17$ $149 \mu \mathrm{mol} \mathrm{J}{ }^{-1}$.

\section{$150 \quad$ 3.2.2. $\gamma$-Ray irradiation}

$151 \gamma$-Ray irradiation was performed with a GSM D1 (Gamma-Service Medical ${ }^{\circledR}$ ) irradiator 152 containing a $123 \mathrm{TBq}{ }^{137} \mathrm{Cs}$ source. This radionuclide disintegrates in ${ }^{137 \mathrm{~m}} \mathrm{Ba}$, which delivers $153661.7 \mathrm{keV} \gamma$-Ray. A dose cartography has been performed by Fricke dosimetry inside the $\gamma$-Ray 154 chamber and the average deposited dose inside the aqueous samples ranges from 7 to $9 \mathrm{~Gy} \min ^{-1}$. 155 As $\gamma$-Ray is a penetrating radiation, the dose is displayed almost equally everywhere inside the 156 sample. 


\subsection{Radiolytic yield calculation}

162 The radiolytic yield $(\mathrm{G})$ is defined as the number of species formed or consumed per unit of

163 deposited energy. It is expressed in the international system by mol $\mathrm{J}^{-1}$ and is calculated at a time

$164 \mathrm{t}$ after transition of the ionizing irradiation according to:

165

$$
G(X)=\frac{X_{t}}{\rho D}
$$

166 where $X_{t}$ is the concentration of the species $X$ at the time $t\left(\mathrm{~mol} \mathrm{~L}^{-1}\right), \rho$ is the density of the

167 irradiated solution $\left(\mathrm{kg} \mathrm{L}^{-1}\right)$ and $\mathrm{D}$ the absorbed dose (in $\mathrm{Gy} ; 1 \mathrm{~Gy}=1 \mathrm{~J} \mathrm{~kg}^{-1}$ of water).

168 The radiolytic yield is actually used to compare different systems and follow the species 169 behavior (i.e. the production/degradation steps). A positive yield means that the species is 170 formed during the irradiation. A negative one means that the species is consumed.

171

\section{Dissolved carbonates degradation mechanism and carboxylates production}

174 In the following sections, we document every step of dissolved carbonate degradation under 175 irradiation. In this aim, radiolytic yields of production/degradation are measured for each 176 involved species according to the following radiolytic process:

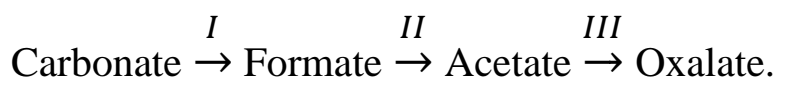

\subsection{Carbonate anions behavior (Step I)}


180 In a previous study (Costagliola et al. 2017), we have investigated the $\gamma$ radiolytic degradation of

181 a $1 \mathrm{mmol} \mathrm{L} \mathrm{L}^{-1}$ calcium carbonate solution as the function of the accumulated dose up to $60 \mathrm{kGy}$.

182 The carbonate degradation yield $\left(\mathrm{G}_{\gamma}\left(-\mathrm{CO}_{3}{ }^{2-}\right)=0.014 \mu \mathrm{mol} \mathrm{\textrm {J } ^ { - 1 }}\right)$ was measured at low dose range

183 (0 to 1000 Gy) under $\gamma$-Ray, thus under low LET. Here, the carbonate degradation was

184 investigated under $\alpha$-beam irradiation in order to determine the G-value which can be assigned to

185 the high LET irradiation (\#He-Carb experiment in Table 1).

186 Figure 1A, shows that the carbonate anions concentration first decreases $\left(\mathrm{G}_{\alpha}\left(-\mathrm{CO}_{3}{ }^{2-}\right)=0.079\right.$

$\left.187 \mu \mathrm{mol} \mathrm{J}{ }^{-1}\right)$ at low applied dose and further re-increases at higher dose $\left(\mathrm{G}_{\alpha}\left(+\mathrm{CO}_{3}{ }^{2-}\right)=0.011 \mu \mathrm{mol} \mathrm{J^{- }}\right.$

$188^{1}$ ). The corresponding production of formate, acetate and oxalate during dissolved carbonate $\alpha$ -

189 beam irradiation is displayed on Figure 1B. The concentration of oxalate increases linearly with

190 the cumulated dose within the 900 to $6000 \mathrm{~Gy}$ range $\left(\mathrm{G}_{\alpha}\left(+\mathrm{C}_{2} \mathrm{O}_{4}{ }^{2-}\right)=1.0 \mathrm{nmol} \mathrm{J^{-1 }}, \mathrm{R}^{2}=0.97\right)$, but

191 both formate and acetate exhibit a steady state concentration above $2000 \mathrm{~Gy}$. Such a behavior 192 remains valid up to $60 \mathrm{kGy}$, as observed by Costagliola et al. 2017. The back-formation of 193 carbonate at high dose and the surprising behavior of the carboxylate byproducts is further 194 discussed below.

A)

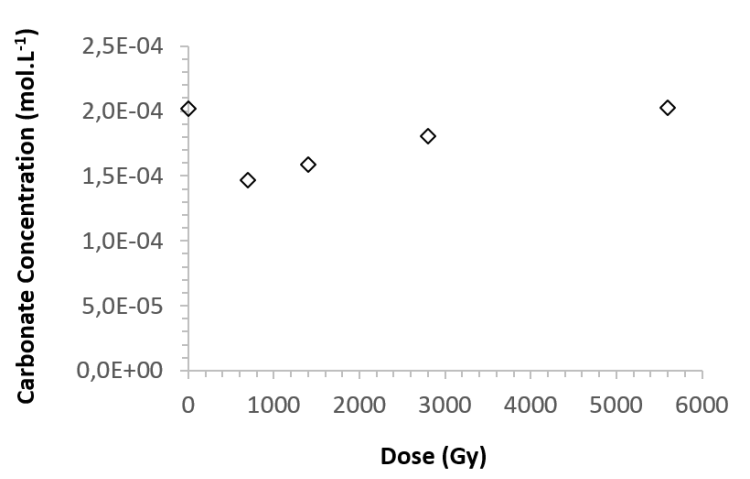

B)

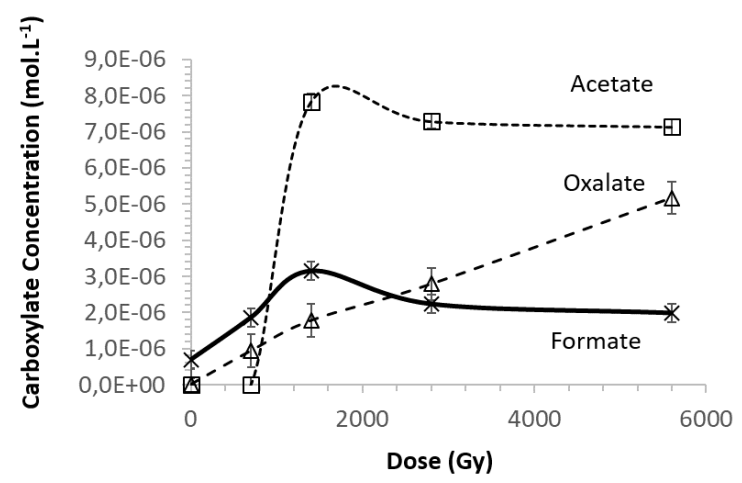


198 Figure 1. A) carbonate, and B) carboxylate anions behavior during $\alpha$-beam irradiation of a 0.2 $199 \mathrm{mmol} \mathrm{L}{ }^{-1}$ carbonate-bearing solution (\#He-Carb, Table 1). Experimental conditions: $\mathrm{E}_{\alpha}=60.7$ $200 \mathrm{MeV}$, Dose Rate $=700-800 \mathrm{~Gy} \min ^{-1}, \mathrm{Ar}$ atmosphere, $\mathrm{pH}=10$.

\subsection{Formate Behavior (Step II)}

204 Formate is the first species produced from the radiolytic degradation of carbonate anions as 205 described in the literature (Costagliola et al. 2017). However, formate is unstable under 206 irradiation and produces other carboxylate anions such as acetate and oxalate. That is the reason 207 why formate stability was extensively studied during this work as a function of different 208 parameters: formate initial concentration, LET effect, and gas production $\left(\mathrm{H}_{2}, \mathrm{CO}_{2}\right)$.

209 First, the back-formation of carbonate associated to reaction step I (carbonate/formate anions

210 mechanism) was demonstrated through the \#He-High-Form experiment (Fig. 2, Table 1).

211 Indeed, carbonates are produced $\left(\mathrm{G}_{\alpha}\left(+\mathrm{CO}_{3}{ }^{2-}\right)=0.098 \mu \mathrm{mol} \mathrm{\textrm {J } ^ { - 1 }}\right)$ when a formate-bearing solution

212 is irradiated using $\alpha$-beam. This latter observation is crucial for understanding the back-

213 formation of carbonate during step I (Fig. 1A). In the same dose range (0-1000 Gy), the 214 comparison between $\mathrm{G} \gamma\left(-0.014 \mu \mathrm{mol} \mathrm{\textrm {J } ^ { - 1 }}\right)$ and $\mathrm{G}_{\alpha}\left(-0.079 \mu \mathrm{mol} \mathrm{J}^{-1}\right)$ for carbonate anions 215 degradation confirmed the critical effect of LET on the enhancement of the radical/radical 216 reactions. Indeed, $\alpha$-beam irradiation favors radical/radical reactions (Eqs. 6 to 8) whereas $\gamma$-Ray 217 irradiation promotes radical/molecular reactions (Eqs. 1 to 5) (Allen 1961). Therefore, the 218 regeneration of carbonate from formate anion radiolysis is triggered by the recombination of 219 radical species such as $\mathrm{CO}_{3}{ }^{\bullet-}$ and $\mathrm{CO}_{2}{ }^{\bullet-}$ (Eqs. 7 to 13). 


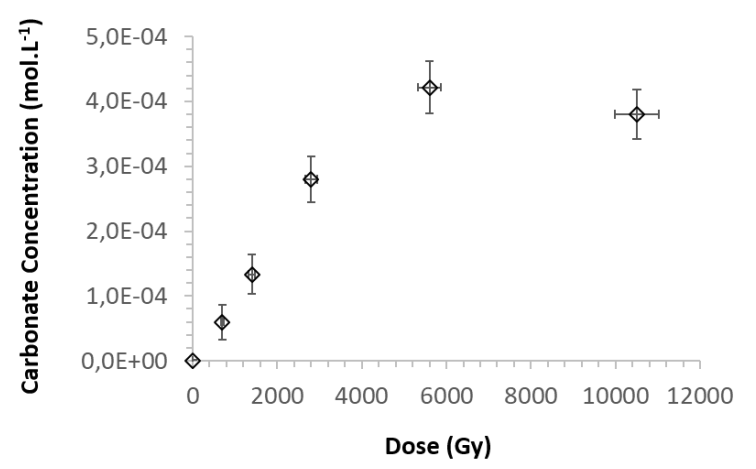

221 Figure 2. Carbonate ion production from $\alpha$-beam irradiation of a $1 \mathrm{mmol} \mathrm{L}^{-1}$ formate-bearing 222 solution (\#He-High-Form, Table 1). Experimental conditions: $\mathrm{E}_{\alpha}=60.7 \mathrm{MeV}, \mathrm{DR}=700-800 \mathrm{~Gy}$ $223 \min ^{-1}$, aerated atmosphere, $\mathrm{pH}=7$.

225 Second, the behavior of formate anions under irradiation was studied as a function of both the

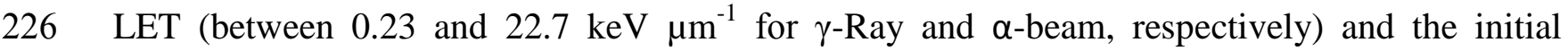
227 concentration in order to establish radiolytic degradation yield for this species. At the low 228 formate concentration $\left(0.01 \mathrm{mmol} \mathrm{L}^{-1}\right)$, the same degradation scheme is observed under both $\gamma$ 229 Ray and $\alpha$-beam irradiation (see Fig. 2 and supplementary Figure S2). Acetate is produced 230 first, then oxalate appears (Fig. 3A). However, the formate degradation yield has been calculated

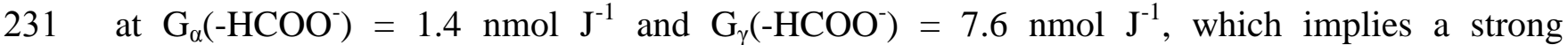
232 dependency upon the radical mechanisms as already underlined (Eqs. 9 to 13). The acetate 233 radiolytic production yield is about the same as the formate degradation one: $\mathrm{G}_{\alpha}\left(+\mathrm{CH}_{3} \mathrm{COO}^{-}\right)=$ $2341.6 \mathrm{nmol} \mathrm{\textrm {J } ^ { - 1 }}$. Thus, there is for low doses a quantitative transformation of formate to acetate. 235 However, oxalate needs an induction period and starts to accumulate at elevated dose $(>2000$ 236 Gy). The corresponding yield is then $\mathrm{G}_{\alpha}\left(+\mathrm{C}_{2} \mathrm{O}_{4}{ }^{2-}\right)=0.6 \mathrm{nmol} \mathrm{J}{ }^{-1}$. 
237 At higher initial concentration $\left(1 \mathrm{mmol} \mathrm{L}^{-1}\right)$, formate radiolysis seems to yield only oxalate (Fig.

238 3B). Probably, acetate remains at a very low concentration compared to formate as it is only an

239 intermediate species between formate and oxalate. The formate consumption yield is by two

240 orders of magnitude higher than in the low-formate concentration medium $\left(\mathrm{G}_{\alpha}\left(-\mathrm{HCOO}^{-}\right)=0.130\right.$

$241 \mu \mathrm{mol} \mathrm{\textrm {J } ^ { - 1 }}$ ). This is basically due to a kinetic effect from the concentration factor. The oxalate yield

242 is here equal to $\mathrm{G}_{\alpha}\left(+\mathrm{C}_{2} \mathrm{O}_{4}{ }^{2-}\right)=0.022 \mu \mathrm{mol} \mathrm{J}{ }^{-1}$. Carbonate regeneration from formate irradiation,

243 as previously described, is the main factor explaining such a low oxalate yield at high initial

244 formate concentration.

245

A

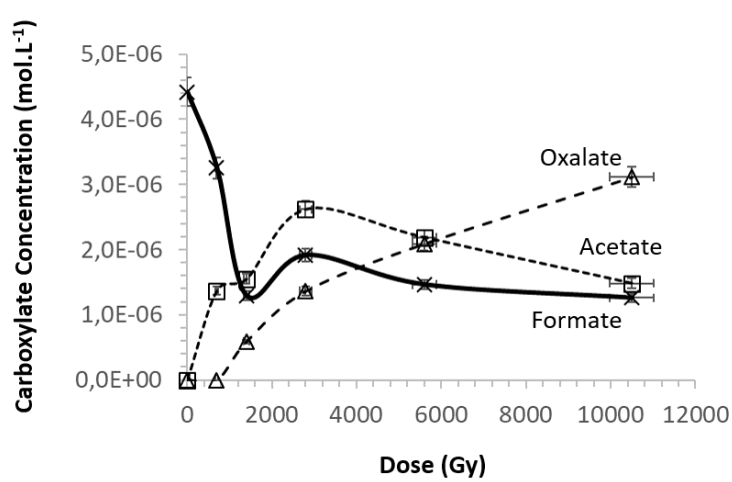

B

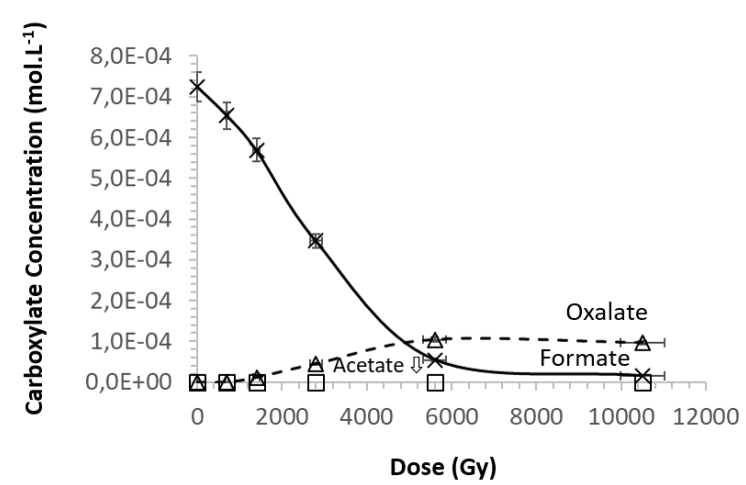

Figure 3. Analysis of the carboxylate ions behavior as a function of $\alpha$-beam irradiation dose for:

248 A) a $0.01 \mathrm{mmol} \mathrm{L}^{-1}$ formate-bearing solution (\#He-Low-Form, Table 1), and B) a $1 \mathrm{mmol} \mathrm{L}^{-1}$

249 formate-bearing solution (\#He-High-Form, Table 1). Experimental conditions: $\mathrm{E}_{\alpha}=60.7 \mathrm{MeV}$,

$250 \mathrm{DR}=700-800 \mathrm{~Gy}^{\mathrm{min}}{ }^{-1}$, aerated atmosphere, $\mathrm{pH}=7$.

252 Third, $\mathrm{H}_{2}$ production during formate, acetate and oxalate degradation was monitored with 253 increasing $\gamma$ dose (Fig. 4, and Table 2). Molecular hydrogen formation by water radiolysis can 254 be explained by the presence of aqueous electrons produced just after irradiation (about $\mu$ s 255 lifetime). These species react with each other to produce $\mathrm{H}_{2}$ according to: 


$$
\mathrm{e}_{\mathrm{aq}}{ }^{-}+\mathrm{e}_{\mathrm{aq}}{ }^{-} \rightarrow \mathrm{H}_{2}+2 \mathrm{OH}^{-} ; \mathrm{k}_{15}=0.55 \times 10^{10} \mathrm{~L} \mathrm{~mol}^{-1} \mathrm{~s}^{-1}
$$

256 However, the Allen chain mechanism, i.e. the recycling of $\mathrm{H}_{2}$ by $\mathrm{OH}^{\bullet}$, keeps $\mathrm{H}_{2}$ production under 257 control (Eqs. 16 and 17). The corresponding $\mathrm{H}_{2}$ radiolytic yield in pure water is then $0.017 \mu \mathrm{mol}$ $258 \mathrm{~J}^{-1}$ (Fig. 4).

$$
\begin{aligned}
& \mathrm{H}_{2}+\mathrm{OH}^{\cdot} \rightarrow \mathrm{H}^{\cdot}+\mathrm{H}_{2} \mathrm{O} ; \mathrm{k}_{16}=4.2 \times 10^{7} \mathrm{~L} \mathrm{~mol}^{-1} \mathrm{~s}^{-1} \\
& \mathrm{H}^{\bullet}+\mathrm{H}_{2} \mathrm{O}_{2} \rightarrow \mathrm{OH}^{\bullet}+\mathrm{H}_{2} \mathrm{O} ; \mathrm{k}_{17}=3.6 \times 10^{7} \mathrm{~L} \mathrm{~mol}^{-1} \mathrm{~s}^{-1}
\end{aligned}
$$

259 In the presence of formate, this yield goes up to $0.11 \mu \mathrm{mol} \mathrm{J^{-1 }}$. This is due to the fact that 260 hydroxyl radical $\mathrm{OH}^{\bullet}$ is efficiently scavenged by formate $\left((\mathbf{1 0})\right.$, which limits the $\mathrm{H}_{2}$ consumption 261 by $\mathrm{OH}^{*}(\mathbf{E q . ~ 1 6})$. Moreover, the kinetic constant of $\mathrm{OH}^{\bullet}$ scavenging by formate ions (Eq. 10) is 262 approximately 100 times higher than the one by $\mathrm{H}_{2}$ (Eq. 16). This enhanced $\mathrm{H}_{2}$ production can 263 be also explained by the scavenging of aqueous electron by formate itself ((12). Both the 264 aqueous electron and the hydroxyl radical $\mathrm{OH}^{*}$ scavenging by formate have similar kinetic 265 constants (Eqs. 12 and 16, respectively). Thus, at constant dose, $\mathrm{H}_{2}$ production will be enhanced 266 in the presence of formate because only one aqueous electron is needed instead of two.

267 Finally, $\mathrm{CO}_{2}$ is also produced from the irradiation of formate solutions. It is the consequence of 268 the reaction between formate and the water radiolysis radicals which forms $\mathrm{CO}_{2}^{-{ }^{-}}$radicals. These 269 radicals are efficiently scavenged by $\mathrm{O}_{2}$ and, in a lesser extent, $\mathrm{H}_{2} \mathrm{O}_{2}$ to produce $\mathrm{CO}_{2}$ according 270 to:

$$
\begin{aligned}
& \mathrm{CO}_{2}^{-\bullet}+\mathrm{O}_{2} \rightarrow \mathrm{CO}_{2}+\mathrm{O}_{2}^{-\bullet} ; \mathrm{k}_{18}=2 \times 10^{9} \mathrm{~L} \mathrm{~mol}^{-1} \mathrm{~s}^{-1} \\
& \mathrm{CO}_{2}^{-\bullet}+\mathrm{H}_{2} \mathrm{O}_{2} \rightarrow \mathrm{CO}_{2}+\mathrm{OH}^{-}+\mathrm{OH}^{-} ; \mathrm{k}_{19}=6 \times 10^{5} \mathrm{~L} \mathrm{~mol}^{-1} \mathrm{~s}^{-1}
\end{aligned}
$$

271 The initial presence of dissolved $\mathrm{O}_{2}$ is not a prerequisite for formate scavenging as water 272 radiolysis itself provides an insitu source of oxidizing species (chiefly $\mathrm{H}_{2} \mathrm{O}_{2}$ and in a lesser extent $273 \mathrm{O}_{2}$ ). Thus, in deep geological settings, the formate radical may be scavenged by $\mathrm{H}_{2} \mathrm{O}_{2}$ produced 274 by water radiolysis (Eq. 19). Hydrogen peroxide was also monitored but no evidence of its 
275 radiolytic production by $\gamma$-Ray of formate, acetate and oxalate solutions has been found. This is a 276 direct consequence of the $\mathrm{OH}^{*}$ scavenging by carboxylates species as the $\mathrm{H}_{2} \mathrm{O}_{2}$ radiolytic 277 formation mechanism is based on $\mathrm{OH}^{*}$ radical recombination (Eqs. 9 and 10). 278

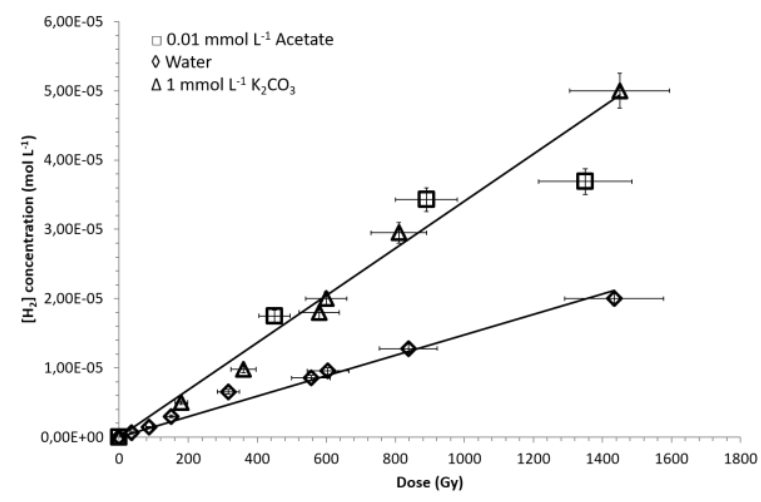

280 Figure 4. Molecular hydrogen radiolytic production after $\gamma$-Ray irradiation of pure water (\#G281 water, losanges, Table 1), a $0.01 \mathrm{mmol} \mathrm{L}^{-1}$ acetate-bearing solution (\#G-Ac, squares, Table 1), 282 and a $1 \mathrm{mmol} \mathrm{L}{ }^{-1} \mathrm{~K}_{2} \mathrm{CO}_{3}$ solution (Costagliola et al. 2017, triangles). Experimental condition: $\mathrm{E}_{\gamma}$ $283=0.6617 \mathrm{MeV}, \mathrm{DR}=7-9 \mathrm{~Gy} \min ^{-1}$, aerated atmosphere, $\mathrm{pH}=7$.

285 Table 2. Molecular hydrogen $\left(\mathrm{G}_{\gamma}\left(+\mathrm{H}_{2}\right)\right)$ and carbon dioxide $\left(\mathrm{G}_{\gamma}\left(+\mathrm{CO}_{2}\right)\right)$ radiolytic $\gamma$ yields.

286 *Data from Costagliola et al. 2017.

\begin{tabular}{lll}
\hline System composition & $\mathbf{G}_{\gamma}\left(+\mathbf{H}_{2}\right) \boldsymbol{\mu m o l ~ J}$ & $\mathbf{G}_{\gamma}\left(+\mathbf{C O}_{2}\right) \mathbf{n m o l ~ J}^{-1}$ \\
\hline Water & 0.017 & 0 \\
Carbonate* $^{*}$ & 0.033 & 3.0 \\
Formate & 0.110 & 7.6 \\
Acetate & 0.037 & 7.0 \\
Oxalate & 0.014 & 12.0 \\
\hline
\end{tabular}


288 In conclusion, the formate degradation mechanism follows two different paths: the first one 289 consists in oxalate formation via acetate intermediate and radical recombination; whereas the 290 second one results in carbonate formation with a non-negligible yield. Oxalate production is thus 291 controlled by the first step of formate consumption.

\subsection{Acetate/Oxalate Anions Behavior (Step III)}

294 The same experiments, as for formate solution, were performed on the samples \#G-Ac and \#G-

295 Ox (Table 1) in order to describe the behavior of acetate and oxalate under $\gamma$-Ray. When 296 exposed to $\gamma$-Ray, acetate behaves very differently to formate. Here, oxalate can accumulate as 297 acetate is degraded during the irradiation (Fig. 5). One can determine the $\mathrm{G}_{\gamma}\left(-\mathrm{CH}_{3} \mathrm{COO}^{-}\right)=9.4$ $298 \mathrm{nmol} \mathrm{\textrm {J } ^ { - 1 }}$ and the $\mathrm{G}_{\gamma}\left(+\mathrm{C}_{2} \mathrm{O}_{4}{ }^{2-}\right)=7.7 \mathrm{nmol} \mathrm{J}{ }^{-1}$ during this experiment.

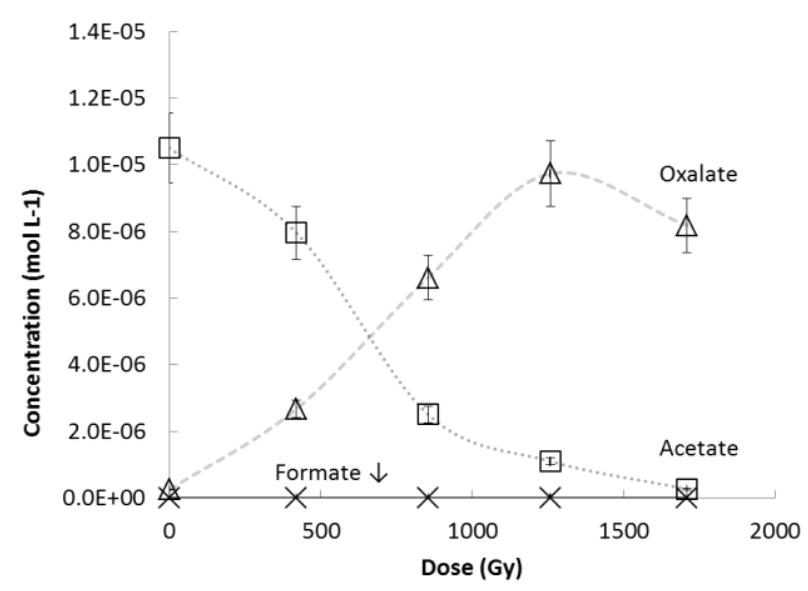

$300 \quad$ Figure 5. Analysis of the carboxylate ions composition from $\gamma$-Ray of a $0.01 \mathrm{mmol} \mathrm{L}^{-1}$ acetate-

301 bearing solution (\#G-Ac, Table 1). Experimental conditions: $\mathrm{E}_{\gamma}=0.6617 \mathrm{MeV}, \mathrm{DR}=7-9$ Gy $302 \min ^{-1}$, aerated atmosphere, $\mathrm{pH}=7$.

304 Similarly, $\alpha$-beam irradiation experiment has been carried out on both 0.01 and $1 \mathrm{mmol} \mathrm{L}^{-1}$ 305 acetate-bearing solutions (\#He-High-Ac and \#He-Low-Ac, respectively, Table 1) (Fig. 6 and 
supplementary Figure S2). At low initial concentration, acetate is degraded by the ionizing

307 radiations leading to oxalate formation which seems to reach a steady-state at elevated dose.

308 Acetate is more stable than formate because its radiolytic consumption yield is more than three

309 times lower than the one of formate $\left(\mathrm{G}_{\alpha}\left(-\mathrm{CH}_{3} \mathrm{COO}^{-}\right)=0.4 \mathrm{nmol} \mathrm{J}{ }^{-1}\right)$. The formate anion

310 formation observed at low dose is followed by a degradation process at elevated dose due to

311 reaction between $\mathrm{CO}_{2}^{-\bullet}$ and $\mathrm{e}_{\mathrm{aq}}{ }^{-}(\mathbf{E q . ~ 8})$. At high initial concentration acetate is not degraded into

312 oxalate during the irradiation. However, the radiolytic consumption yield of acetate remains in

313 good agreement $\left(\mathrm{G}_{\alpha}\left(-\mathrm{CH}_{3} \mathrm{COO}^{-}\right)=0.049 \mu \mathrm{mol} \mathrm{\textrm {J } ^ { - 1 }}\right)$ with the one measured at $0.01 \mathrm{mmol} \mathrm{L}^{-1}$.

314 From a carbon mass balance point of view, it can be noticed that up to $50 \mathrm{~mol} \%$ of carbon cannot

315 be assigned to the dissolved carboxylate anions quantified in this work. This is particularly

316 evident at high formate or acetate initial concentration (Fig. 3B and 6B). An important part of

317 this discrepancy may be explained by $\mathrm{CO}_{2}$ degassing (as measured in part 4.2), but minor

318 hydrocarbons (methane, ethane), organic polymers, and formaldehyde may also be produced

319 (Draganić et al. 1991). Methane, however, has not been detected in these experiments (detection

320 limit $=5 \mathrm{ppm})$, and the other species were not analyzed.

A

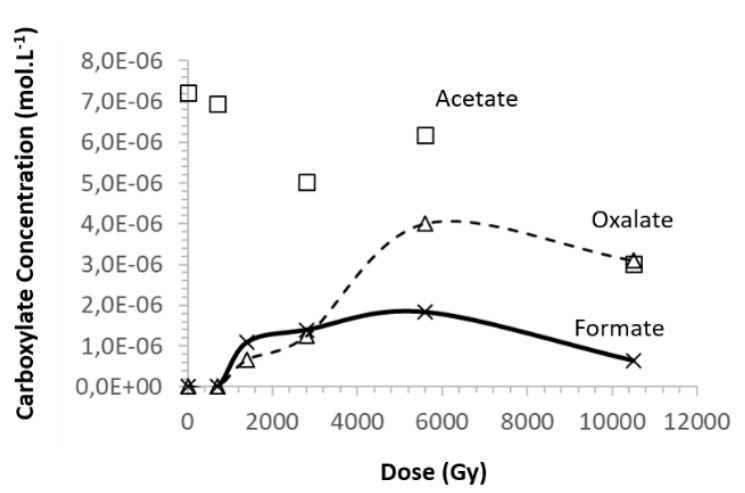

B

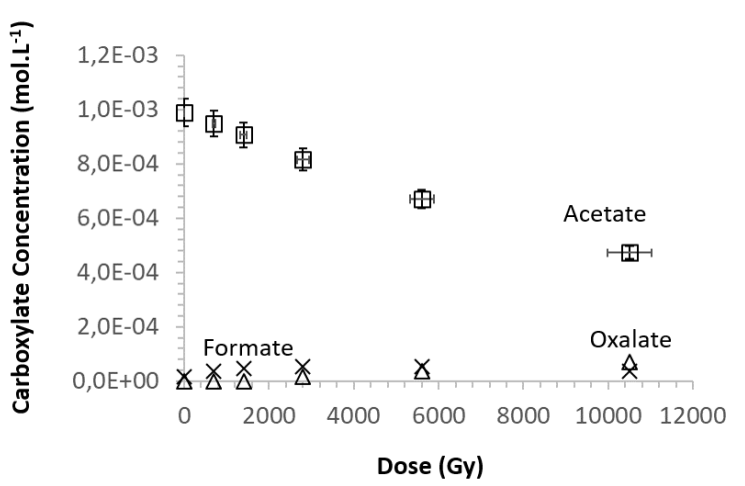

323 Figure 6. Analysis of the carboxylate ions composition from $\alpha$-beam irradiation of: A) a 0.01

324 mmol L ${ }^{-1}$ acetate-bearing solution (\#He-High-Ac, Table 1), and B) a $1 \mathrm{mmol} \mathrm{L}^{-1}$ acetate bearing 
325 solution (\#He-Low-Ac, Table 1). Experimental conditions $\mathrm{E}_{\alpha}=60.7 \mathrm{MeV}, \mathrm{DR}=700-800 \mathrm{~Gy}$

$326 \min ^{-1}$, aerated atmosphere, $\mathrm{pH}=7$.

327 The comparison of acetate degradation at low concentration $\left(0.01 \mathrm{mmol} \mathrm{L}^{-1}\right)$ under either $\alpha$-beam 328 or $\gamma$-Ray (Figs. 5 and 6A, respectively), reveals a major effect of LET. Indeed, under $\gamma$-Ray, 329 acetate is fully degraded into oxalate at a relatively low dose (1600 Gy), whereas only $50 \%$ of 330 acetate is degraded into oxalate and minor formate at elevated $\alpha$-beam irradiation dose (10500 331 Gy). Thus, the radiolytic degradation of acetate anions at low concentration $\left(0.01 \mathrm{mmol} \mathrm{L}^{-1}\right)$ 332 seems to mainly occur through radical reactions. These latter processes compete with the formate 333 radical/radical reactions which produce oxalate anions (Eq. 6). However, these radical 334 recombinations at play during acetate irradiation imply a lower $\mathrm{H}_{2}$ production compare to the one 335 measured with formate (see part 4.2). At high $\left(1 \mathrm{mmol} \mathrm{L}^{-1}\right)$ acetate concentration, either the 336 acetate anion itself scavenges all the formate radical or both acetate and formate react together to 337 produce a more complex unidentified molecule.

338 Finally, concerning the results of the oxalate anions behavior under both $\alpha$-beam and $\gamma$-Ray 339 irradiations (\#He-High-Ox, \#He-low-Ox, and \#G-Ox; Table 1) no change in concentration is 340 observed for a large range of dose (up to $40 \mathrm{kGy}$ ) whatever both the radiation and the initial 341 oxalate concentration within the $0.01-1 \mathrm{mmol} \mathrm{L}^{-1}$ oxalate concentration range.

\subsection{Summary of Yields-G}

344 As a summary, Table 3 compiles the different radiolytic yields of species consumption and 345 formation due to both $\alpha$-beam and $\gamma$-Ray irradiations, as determined in this study. 
Table 3. Summary of the radiolytic yields of carbonate, formate, acetate and oxalate production/degradation due to both $\alpha$-beam and $\gamma$-Ray irradiations as determined from the experiments performed in this work. * Data from Cai et al. (2001). bdl= below detection $351 \quad$ limit

\begin{tabular}{|c|c|c|c|c|c|c|c|}
\hline \multirow{2}{*}{$\begin{array}{l}\text { Irradiated } \\
\text { medium }\end{array}$} & \multirow{2}{*}{$\begin{array}{l}\text { Concent. } \\
\left(\mathrm{mmol} \mathrm{L}^{-1}\right)\end{array}$} & \multicolumn{3}{|c|}{ Yields $\mathbf{G}_{\alpha}\left(\mathrm{nmol}^{-1}\right)$} & \multicolumn{3}{|c|}{ Yields $\mathbf{G}_{\gamma}\left(\mathrm{nmol}^{-1}\right)$} \\
\hline & & Formate & Acetate & Oxalate & Formate & Acetate & Oxalate \\
\hline Carbonate & 0.2 & $0.4 \pm 0.2$ & $1.7 \pm 0.9$ & $1.0 \pm 0.1$ & & & $2 *$ \\
\hline \multirow{2}{*}{ Formate } & 0.01 & -1.4 & 1.6 & 0.59 & -7.6 & $b d l$ & $b d l$ \\
\hline & 1 & -130 & 0 & 22 & & & \\
\hline \multirow{2}{*}{ Acetate } & 0.01 & 0.48 & -0.36 & 0.84 & -9.4 & $b d l$ & 7.7 \\
\hline & 1 & 0 & -49 & 0 & & & \\
\hline \multirow{2}{*}{ Oxalate } & 0.01 & 0 & 0 & 0 & 0 & 0 & 0 \\
\hline & 1 & 0 & 0 & 0 & & & \\
\hline
\end{tabular}

354 Among the radiolytic yields reported in Table 3, only those concerning oxalate production can

355 be applied over a large dose range, i.e. at least from 0 to $60 \mathrm{kGy}$. All the other yields are valid at 356 low dose (typically 0 to $2000 \mathrm{~Gy}$ ). This is because acetate and formate are intermediate species 357 during carbonate degradation to oxalate.

358 From a geological perspective, and based on the detail understanding of the carbonate 359 degradation mechanism presented here, we propose to use the oxalate production yield as a way 360 to infer the carboxylate anions concentration in long residence time groundwaters where the 361 cumulated dose can be very high. The oxalate production yield from carbonate irradiation is 362 weakly affected by the LET compare to the other species. The G-value for oxalate production 363 reported here under $\alpha$-beam irradiation is $1 \mathrm{nmol} \mathrm{J}^{-1}$, whereas Cai et al. 2001 indicate a G-value 
364 of $2 \mathrm{nmol} \mathrm{J}^{-1}$ under $\gamma$-Ray. Once oxalate concentration is known, one can derive the steady state

365 concentration of formate and acetate depending on the dose and the initial concentration of

366 carbonate. Under alkaline condition, it is interesting to note that the steady state concentration of

367 formate and acetate seems to decreases when carbonate concentration increases. In this study, at

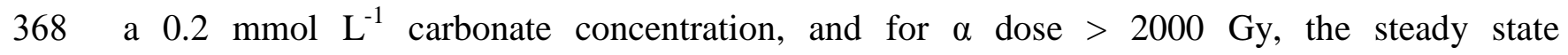

369 concentrations of formate and acetate are at 1.8 and $7.0 \mu \mathrm{mol} \mathrm{L}^{-1}$, respectively. Under the same

370 irradiation condition, but at a five-time higher carbonate concertation $\left(1 \mathrm{mmol} \mathrm{L}^{-1}\right)$, Costagliola

371 et al. 2017 report a steady state formate and acetate concentration of 1.2 and $3.5 \mu \mathrm{mol} \mathrm{L} \mathrm{L}^{-1}$,

372 respectively. Cai et al. 2001 did not succeed to detect formate and acetate (detection limit $=1$

$373 \mu \mathrm{mol} \mathrm{L}{ }^{-1}$ ) after $\gamma$-Ray irradiation of a $50 \mathrm{mmol} \mathrm{L}^{-1}$ carbonate-bearing solution.

375 5. Estimation of radiolytic carboxylate anions production in natural settings

376 In a given geological setting, the radiolytic oxalate production yield determined in this study

$377\left(\mathrm{G}_{\alpha}\left(+\mathrm{C}_{2} \mathrm{O}_{4}{ }^{2-}\right)=1 \mathrm{nmol} \mathrm{J}{ }^{-1}\right)$, combined with the respective natural doses from $\alpha-, \beta-$, and $\gamma-$

378 radiations can be used to calculate the radiation-induced oxalate production rate from carbonate

379 degradation. Several examples are displayed in Table 4 for different subsurface environments

380 with contrasted concentration of radioactive elements including Cigar Lake U-ore deposits

381 (Canada), carbon leaders in the Witwatersrand basin (South Africa), granites in the

382 Fennoscandian shield (Eurojaki Rapakivi, Finland), basalts in the Columbia River Basalt

383 province, quartzites in the Witwatersrand Supergroup (South Africa), and sediments in the

384 Taylorsville basin (Virginia, USA). Radiation doses have been computed by Truche et al. 2018

385 for Cigar Lake U-ore deposit, and by Lin et al. 2005 for the other settings. 
386 The radiolytic oxalate production rate ranges from $10^{-10}$ to $10^{-5} \mathrm{nM} \mathrm{s}^{-1}$ (Table 4) and depends 387 chiefly on the radioactive elements content of the rock. Porosity in itself has only a minor impact 388 on the oxalate production rates as most of the radiation energy (i.e. $>99 \%$ ) is dissipated in the 389 solids and not absorbed by pore water (Truche et al. 2018). The obtained oxalate production rates 390 are about 50 time lower than the radiolytic $\mathrm{H}_{2}$ production rate reported by Lin et al. 2005 and 391 Truche et al. 2018 for these geological environments, but they remain sufficiently high to sustain 392 significant oxalate concentration in long residence time groundwaters. Without surprise, the 393 Cigar Lake U deposit has the highest oxalate production rate $\left(5.2 \times 10^{-6} \mathrm{nM} \mathrm{s}^{-1}=0.16 \mathrm{M} \mathrm{Myr}^{-1}\right)$.

394 Such a rate, together with a residence time of groundwater in the deposit of $0.1 \mathrm{Ma}$ (Cramer and 395 Smellie 1994), would imply a radiation-induced oxalate concentration as high as $16 \mathrm{mM}$. The 396 groundwater in the Witwatersrand Supergroup has the lowest oxalate production rate $\left(1.2 \times 10^{-10}\right.$ $397 \mathrm{nM} \mathrm{s}^{-1}=3.8 \mu \mathrm{M} \mathrm{Myr}^{-1}$ ), but its subsurface residence time spans from 3 to $80 \mathrm{Ma}$ (Lippmann et 398 al. 2003), which for these groundwater ages translates into $10 \mu \mathrm{M}$ to $0.3 \mathrm{mM}$ oxalate 399 concentration. Whatever the context, the steady state concentration of formate and acetate 400 produced would range from 1 to $10 \mu \mathrm{M}$.

401 Our estimates suggest that radiolysis can produce millimolar concentration of oxalate and 402 micromolar levels of formate and acetate in ancient water from deep crystalline bedrocks if there 403 is no biological or abiotic consumption. Such a reaction process does not require specific catalyst 404 or hydrothermal condition to occur. The continuous production of carboxylate species from 405 radiolytic origin, and their weak mobility compare to $\mathrm{H}_{2}$, may promote their persistence in deep 406 groundwater.

407 Another important consequence of carbonate radiolysis lies in an enhanced $\mathrm{H}_{2}$ production 408 compared to pure water radiolysis. Dissolved carbonates are ubiquitous in natural geological 
409 settings, and $\mathrm{H}_{2}$ production is probably much more important than previously anticipated on the

410 basis of $\mathrm{H}_{2}$ yield derived from carbonate-free solutions. Here, we demonstrate that $\mathrm{H}_{2}$ production

411 from dissolved carbonate radiolysis is enhanced by a factor 2 compare to pure water (Table 2).

412

413 Table 4. Radiolytic oxalate yield rates in various natural settings. Calculations for the net dose

414 rates are from Lin et al. 2005 and Truche et al. 2018.

\begin{tabular}{|c|c|c|c|c|c|c|c|c|}
\hline $\begin{array}{c}\text { Rock type } \\
\text { (location) }\end{array}$ & $\begin{array}{c}\text { Porosity } \\
(\%)\end{array}$ & $\begin{array}{c}\mathbf{U} \\
(\mathbf{p p m})\end{array}$ & $\begin{array}{c}\text { Th } \\
\text { (ppm) }\end{array}$ & $\begin{array}{c}\mathbf{K} \\
(\%)\end{array}$ & $\begin{array}{c}\alpha \text {-dose rate } \\
\left(\mathrm{Gy} \mathrm{s}^{-1}\right)\end{array}$ & $\begin{array}{c}\beta \text {-dose rate } \\
\left(\mathrm{Gy} \mathrm{s}^{-1}\right)\end{array}$ & $\begin{array}{c}\gamma \text {-dose rate } \\
\left(\mathrm{Gy} \mathrm{s}^{-1}\right)\end{array}$ & $\begin{array}{c}\text { Oxalate rate } \\
\left(\mathrm{nM} \mathrm{s}^{-1}\right)\end{array}$ \\
\hline $\begin{array}{l}\text { U-ore deposit } \\
\text { (Cigar Lake) }\end{array}$ & 10 & 140,000 & nd & nd & $1.01 \times 10^{-6}$ & $3.23 \times 10^{-6}$ & $9.67 \times 10^{-7}$ & $5.21 \times 10^{-6}$ \\
\hline $\begin{array}{l}\text { Carbon leaders } \\
\text { (Witwatersrand } \\
\text { basin) }\end{array}$ & 0.1 & 40,000 & 8000 & 1 & $4.3 \times 10^{-6}$ & $2.4 \times 10^{-11}$ & $5.0 \times 10^{-8}$ & $4.31 \times 10^{-6}$ \\
\hline $\begin{array}{l}\text { Granite } \\
\text { (Fennoscandian } \\
\text { Shield) }\end{array}$ & 0.1 & 10 & 30 & 5.0 & $1.7 \times 10^{-9}$ & $1.2 \times 10^{-10}$ & $6.8 \times 10^{-11}$ & $1.89 \times 10^{-9}$ \\
\hline $\begin{array}{l}\text { Basalts } \\
\text { (Columbia River) }\end{array}$ & 0.1 & 1 & 3 & 0.8 & $1.7 \times 10^{-10}$ & $1.9 \times 10^{-11}$ & $9.7 \times 10^{-12}$ & $1.90 \times 10^{-10}$ \\
\hline $\begin{array}{l}\text { Quartztites } \\
\text { (Witwatersrand } \\
\text { Supergroup) }\end{array}$ & 0.1 & 2 & 11 & 2 & $4.9 \times 10^{-11}$ & $4.6 \times 10^{-11}$ & $2.4 \times 10^{-11}$ & $1.19 \times 10^{-10}$ \\
\hline $\begin{array}{l}\text { Sediments } \\
\text { (Taylorsville } \\
\text { Basin) }\end{array}$ & 0.1 & 5 & 15 & 2.5 & $8.7 \times 10^{-10}$ & $6.5 \times 10^{-11}$ & $3.4 \times 10^{-11}$ & $9.69 \times 10^{-10}$ \\
\hline
\end{tabular}

416 6. Implication for abiotic synthesis of organic compounds in geological settings

417 Carbonate radiolysis chiefly produces oxalate and leads to a boost of $\mathrm{H}_{2}$ generation compare to

418 pure water radiolysis. These two compounds are excellent energy sources, which can be oxidized

419 by anaerobic microorganisms with nitrate, ferric iron, sulfate, or carbon dioxide as electron

420 acceptors. Traditional perception of the metabolism of deep-dwelling microbes is that they are

421 chemolithoautotrophic using inorganic carbon and $\mathrm{H}_{2}$ as their energy source (Chapelle et al.

422 2002, Lin et al. 2005, Nealson et al. 2005). However, there is increasing evidence that organic

423 acids sustained bacteria play a quantitatively important role in biological organic carbon cycling 
424 in the marine and terrestrial deep biosphere (Heuer et al. 2009, Lever et al. 2010, Weiss et al.

425 2016; Pisapia et al. 2017). Among all the acetogenic substrates, oxalate oxidation can produce

426 energy yields exceeding the thermodynamic threshold concentration for growth and replication

427 in the deep subsurface (Lever 2012).

428 Bacteria capable of using oxalate as a sole carbon and energy source have been recognized as an

429 important part of the biogeochemical carbon cycle (Sahin 2003). More than 50 species of

430 oxalotrophic bacteria have been identified to date, some of these bacteria are generalists because

431 they are able to ferment many other substrates, but some others are "specialists" because they

432 only use oxalate as energy source, like clostridium thermoaceticum (Daniel and Drake 1993). In

433 addition, oxalate can also be used by fermenters that form formates and bicarbonates. If

434 ecosystems are present, some feedback loops are possible. Although fermentation is not as

435 energetically favorable as respiration, such a process does not need any electron acceptors, which

436 can be an advantage in reduced environments such as ancient cratons.

437 Primordial life, as inferred back from modern genomes, is depicted as a strictly anaerobic, $\mathrm{H}_{2}$ -

438 dependent thermophilic, diazotrophic autotroph with an Acetyl-CoA pathway and living in a

439 hydrothermal vent setting (Weiss et al. 2016). These are attributes of clostridia acetogens

440 lineages that branch deeply in trees of the last universal common ancestor genes and that occupy

441 the Earth's crust today.

442 This cannot hide the fact that actual concentration of oxalate has not been measured in deep

443 crustal fluids, however. Only $\mathrm{H}_{2}$, formate, and acetate concentration data have been published for

444 the deep subsurface biosphere (e.g. Sherwood Lollar et al. 2021). If some recent studies have

445 documented trace amounts of long chain monocarboxylic acids (propionate, butanoate,

446 pentanoate, hexanoate, and lactate), the presence of dicarboxylic acids, like oxalate, has never 
447 been reported in deep facture waters (Kieft et al. 2018, Onstott et al. 2009). This later species

448 may be microbiologically consumed or may have been overlooked as the total dissolved organic

449 carbon content measured in these environments is systematically higher to the combined

450 concentration of all dissolved organic species taken individually, indicating the presence of

451 substantial amounts of unclassified organic species. Oxalate is frequently reported in deep

452 sedimentary brines (Giordano and Kharaka 1994) and paleofluids entrapped in minerals (Zeng et

453 al. 2002), even if it represents a minor component of all the dissolved carboxylate anions

454 measured in formation waters. However, among all the carboxylic acids, oxalate displays some

455 unique properties that may explain its low concentration in deep crustal fluids. First, it is much

456 more unstable under hydrothermal condition than acetate or formate. At $80^{\circ} \mathrm{C}$, oxalate half-life

457 ranges from 2500 to 28,000 years at $\mathrm{pH}$ values of 5 and 7, respectively (Crossey 1991). Aqueous

458 complexation decreases significantly (2 to 3 order of magnitude) the decarboxylation rate of

459 oxalate (Fein et al. 1994), but does not change the relative stability of carboxylate species under

460 prevailing hydrothermal conditions. Second, oxalate has a strong affinity for mineral surfaces

461 and it is known to catalyze mineral dissolution (Cama and Ganor 2006, Cheah et al. 2003, Mast

462 and Drever 1987). Adsorption at the surface of silicates and oxy-hydroxides may efficiently

463 decrease oxalate concentration in solution. Third, it is the only organic acid that naturally forms

464 solid phases such as whewellite $\left(\mathrm{CaC}_{2} \mathrm{O}_{4} \cdot \mathrm{H}_{2} \mathrm{O}\right)$ and weddelite $\left(\mathrm{CaC}_{2} \mathrm{O}_{4} \cdot 2 \mathrm{H}_{2} \mathrm{O}\right)$ (Hofmann and

465 Bernasconi 1998). These Ca oxalate minerals are poorly soluble in circumneutral-alkaline

466 aqueous solution (Streit et al. 1998) and their existence has been documented in a wide variety of

467 diagenetic and hydrothermal environments and even in meteorites (Fuchs et al. 1973, Pizzarello

468 and Garvie 2014). The presence of oxalate in hydrothermal environments constitute clear

469 evidence that oxalic acid was an important constituent of many paleofluids (Hofmann and 
470 Bernasconi 1998). Interestingly, oxalate-bearing phases are frequently associated with uraninite.

471 An origin of oxalate as a result of radiolysis has been postulated based on field and laboratory

472 evidence (Hasselstrom and Henry 1956; Hofmann and Bernasconi 1998). Thus, minerals may be

473 an overlooked reservoir of oxalate in deep geological environments. In addition, oxalate can be

474 consumed by fermenters that form formates and bicarbonates. Oxalate concentrations have either

475 not been reported and are below detection limits to date for most fracture fluids studied in deep

476 crystalline bedrock. This study suggests that oxalate should be a priority target analyte for future

477 studies in these environments.

478 Carbonate radiolysis provide a consistent pathway for both enhancing the radiolytic $\mathrm{H}_{2}$ 479 production and generating carboxylic species potentially available for microbes. Accordingly, 480 life in deep groundwater environments may not be solely supported by $\mathrm{H}_{2}$ derived from abiotic 481 water-rock interactions or by $\mathrm{CH}_{4}$ and short-chain organic acids generated from geogenic $\mathrm{H}_{2}$ via 482 Fischer-Tropsch-type synthesis (Ménez 2020, Reeves and Fiebig 2020). This finding has also 483 interesting implication for prebiotic chemistry and the development of life on other planets. In an 484 extraterrestrial context, radiolysis has been considered as an $\mathrm{H}_{2}$ production mechanism on Mars 485 (Tarnas et al. 2018), Enceladus (Waite et al. 2017) and Europa (Bouquet et al. 2017). In addition 486 to $\mathrm{H}_{2}$, it is now interesting to consider the radiolytic production of carboxylate anions as key 487 chemical components to support a subsurface biosphere. It has been suggested that salts of oxalic 488 acids should be present in the Martian regolith, as they would be the primary end-products of 489 meteoritic organic matter oxidative decomposition (Applin et al. 2015). We argue here that 490 carbonate radiolysis can be an endogenous source of oxalate on Mars and other planetary bodies. 


\section{7. Conclusion}

496 Radiation-induced carbonate degradation leads to both a boost of radiolytic $\mathrm{H}_{2}$ production and 497 the formation of carboxylate anions. At low dose, formate and acetate are favored whereas at 498 higher dose oxalate is the most stable organic species. The carbonate radiolytic degradation 499 follows a 3 steps reaction mechanism (Carbonate $\stackrel{I}{\rightarrow}$ Formate $\stackrel{I I}{\rightarrow}$ Acetate $\stackrel{I I I}{\rightarrow}$ Oxalate).

500 (I) The formate anion formation is balanced by a re-production of carbonate due to formate 501 degradation under $\alpha$-beam irradiation.

502 (II) The formate breaks down the Allen chain by hydroxyl scavenging and increases drastically $503 \mathrm{H}_{2}$ production. Formate radical is scavenged by dioxygen and produces carbon dioxide gas. 504 Acetate is an intermediate species during the formate/oxalate degradation.

505 (III) Acetate degradation involves formate radical, and finally oxalate is strongly resistant under 506 irradiation whatever the beam considered ( $\alpha$-beam or $\gamma$-Ray).

507 G-yields values of each carboxylate anions considered (formate/acetate/oxalate) are measured in 508 low carbonate concentration solutions $\left(0.01\right.$ to $\left.1 \mathrm{mmol} \mathrm{L}^{-1}\right)$ exposed to $\alpha$-beam or $\gamma$-Ray. These 509 values together with the calculated dose rate and groundwater residence time allow the 510 carboxylate anions concentration to be estimated in various deep geological settings. Irradiation511 induced oxalate concentration may reach the millimolar range in deep ancient fracture fluids. 512 This finding support the hypothesis that radiolytic carboxylates, with oxalate at the forefront, 513 may contribute to fuel the deep subsurface lithotrophic microbial ecosystems as radiolytic $\mathrm{H}_{2}$ 514 does (Lin et al. 2005). 
515 Carbonate radiolysis, may also produce other organic compounds such as formaldehyde and 516 polymeric material (molecular weight: 14000-16000 daltons), this later being unidentified so far

517 (Draganić et al. 1991). It is now of primary importance to reveal the yield and production

518 mechanism of these organic species as they may also constitute an important part of the abiotic

519 organic compounds available for the deep microbial ecosystems. Radiolysis is also known to be

520 strongly affected by surface-mediated or catalytic reactions. The mechanisms and yields of

521 carboxylate species measured here remain to be evaluated in the presence of minerals and

522 particularly at the solid/solution interface where the specific surface area plays a major role in

523 radiolytic gaseous species generation. Finally, the $\mathrm{C}, \mathrm{H}$ isotopic signatures of carboxylate species

524 produced experimentally during carbonate radiolysis and measured in deep fractured fluids have

525 to be documented in order to improve the knowledge of their source.

\section{ACKNOWLEDGMENT}

528 Grateful thanks to Associate editor Prof. Frederic Moynier. The authors warmly thank 529 Benedicte Menez, Barbara Sherwood Lollar, and an anonymous reviewer for their very 530 constructive reviews. This work has been supported in part by a grant from the French National 531 Agency for Research called "Investissements d'Avenir", Equipex ArronaxPlus nºAR-11532 EQPX-0004 and ISITE NExT $n^{\circ}$ ANR-16-IDEX-0007. The authors would like to express their 533 gratitude for the ARRONAX facility teams for their technical support in this study. L. Truche 534 acknowledges support from the Institut Universitaire de France and the Mission for 535 Interdisciplinary initiative (MITI) from CNRS.

\section{REFERENCES}


Albarrán, G., Collins, K.E., Collins, C.H., 1987. Formation of organic products in self-radiolyzed calcium carbonate. J. Mol. Evol. 25, 12-14.

539 Albarrán, G., Collins, K.E., Collins, C.H., 1994. Organic products from the gamma radiolysis of 540 Ca14CO3. Radiation Physics and Chemistry 43, 307-309.

541 Allen, A.O., 1961. The Radiation Chemistry of Water and Aqueous Solutions, Princeton, USA.

542 Applin, D.M., Izawa, M.R.M., Cloutis, E.A., Goltz, D., Johnson, J.R., 2015. Oxalate minerals on 543 Mars? Earth Planet. Sci. Lett. 420, 127-139.

544 Bomberg, M., Lamminmäki, T., Itävaara, M., 2016. Microbial communities and their predicted 545 metabolic characteristics in deep fracture groundwaters of the crystalline bedrock at Olkiluoto, 546 Finland. Biogeosciences 13, 6031.

547 Bouquet, A., Waite, J.H., Glein, C.R., Wyrick, D., 2017. Alternative Energy: Production of H_2 548 by Radiolysis of Water in the Rocky Cores of Icy Bodies. Astrophysical Journal Letters 840, 7.

549 Cai, Z., Li, X., Katsumura, Y., Urabe, O., 2001. Radiolysis of Bicarbonate and Carbonate 550 Aqueous Solutions: Product Analysis and Simulation of Radiolytic Processes. Nuclear 551 Technology 136, 231-240.

552 Cama, J., Ganor, J., 2006. The effects of organic acids on the dissolution of silicate minerals: A 553 case study of oxalate catalysis of kaolinite dissolution. Geochimica et Cosmochimica Acta 70, 554 2191-2209.

555 Chapelle, F.H., O'Neill, K., Bradley, P.M., Methé, B.A., Ciufo, S.A., Knobel, L.L., Lovley, D.R., 556 2002. A hydrogen-based subsurface microbial community dominated by methanogens. Nature $557415,312-315$.

558 Cheah, S.-F., Kraemer, S.M., Cervini-Silva, J., Sposito, G., 2003. Steady-state dissolution 559 kinetics of goethite in the presence of desferrioxamine B and oxalate ligands: implications for the 560 microbial acquisition of iron. Chem. Geol. 198, 63-75.

561 Costagliola, A., Vandenborre, J., Blain, G., Baty, V., Haddad, F., Fattahi, M., 2017. Radiolytic 562 Dissolution of Calcite under Gamma and Helium Ion Irradiation. J. Phys. Chem. C 121, 2454856324556.

564 Cramer, J.J., Smellie, J.A.T., 1994. Final report of the AECL/SKB Cigar Lake analog study, 565 Canada, p. 393.

566 Crossey, L.J., 1991. Thermal degradation of aqueous oxalate species. Geochimica et 567 Cosmochimica Acta 55, 1515-1527.

568 Daniel, S.L., Drake, H.L., 1993. Oxalate- and Glyoxylate-Dependent Growth and Acetogenesis 569 by $<\mathrm{em}>$ Clostridium thermoaceticum</em>. Appl. Environ. Microbiol. 59, 3062-3069. 
570 Draganić, Z.D., Negrón-Mendoza, A., Sehested, K., Vujošević, S.I., Navarro-Gonzáles, R., 571 Albarrán-Sanchez, M.G., Draganić, I.G., 1991. Radiolysis of aqueous solutions of ammonium 572 bicarbonate over a large dose range. International Journal of Radiation Applications and 573 Instrumentation. Part C. Radiation Physics and Chemistry 38, 317-321.

574 Fein, J., Yane, L., Handa, T., 1994. The effect of aqueous complexation on the decarboxylation 575 rate of oxalate. Geochimica et Cosmochimica Acta 58, 3975-3981.

576 Fones, E.M., Colman, D.R., Kraus, E.A., Nothaft, D.B., Poudel, S., Rempfert, K.R., Spear, J.R., 577 Templeton, A.S., Boyd, E.S., 2019. Physiological adaptations to serpentinization in the Samail 578 Ophiolite, Oman. The ISME Journal 13, 1750-1762.

Fricke, H., Hart, E.J., 1966. Chemical Dosimetry, Radiation Dosimetry. Academic Press, New 580 York, USA.

581 Fuchs, L.H., Olsen, E., Jensen, K.J., 1973. Mineralogy, Mineral-Chemistry, and Composition of 582 the Murchison (C2) Meteorite. Smithsonian Contributions to the Earth Sciences. 1-39.

583 Giordano, T.H., Kharaka, Y.K., 1994. Organic ligand distribution and speciation in sedimentary 584 basin brines, diagenetic fluids and related ore solutions. Geological Society, London, Special 585 Publications 78, 175-202.

586 Hasselstrom, T., Henry, M.C., 1956. New Synthesis of Oxalic Acid. Science 123, 1038-1039.

587 Heuer, V.B., Pohlman, J.W., Torres, M.E., Elvert, M., Hinrichs, K.-U., 2009. The stable carbon 588 isotope biogeochemistry of acetate and other dissolved carbon species in deep subseafloor 589 sediments at the northern Cascadia Margin. Geochimica et Cosmochimica Acta 73, 3323-3336.

590 Hoehler, T.M., Jørgensen, B.B., 2013. Microbial life under extreme energy limitation. Nature 591 Reviews Microbiology 11, 83-94.

592 Hofmann, B.A., Bernasconi, S.M., 1998. Review of occurrences and carbon isotope 593 geochemistry of oxalate minerals: implications for the origin and fate of oxalate in diagenetic 594 and hydrothermal fluids. Chem. Geol. 149, 127-146.

595 Holland, G., Sherwood Lollar, B., Li, L., Lacrampe-Couloume, G., Slater, G.F., Ballentine, C.J., 596 2013. Deep fracture fluids isolated in the crust since the Precambrian era. Nature 497, 357-360.

597 Kieft, T.L., Walters, C.C., Higgins, M.B., Mennito, A.S., Clewett, C.F.M., Heuer, V., Pullin, 598 M.J., Hendrickson, S., van Heerden, E., Sherwood Lollar, B., Lau, M.C.Y., Onstott, T.C., 2018. 599 Dissolved organic matter compositions in 0.6-3.4 km deep fracture waters, Kaapvaal Craton, 600 South Africa. Org. Geochem. 118, 116-131.

601 Klein, F., Tarnas, J.D., Bach, W., 2020. Abiotic Sources of Molecular Hydrogen on Earth. 602 Elements 16, 19-24. 
Lang, S.Q., Früh-Green, G.L., Bernasconi, S.M., Brazelton, W.J., Schrenk, M.O., McGonigle, J.M., 2018. Deeply-sourced formate fuels sulfate reducers but not methanogens at Lost City hydrothermal field. Scientific Reports 8, 755.

Lever, M., 2012. Acetogenesis in the Energy-Starved Deep Biosphere - A Paradox? Frontiers in Microbiology 2.

608 Lever, M.A., Heuer, V.B., Morono, Y., Masui, N., Schmidt, F., Alperin, M.J., Inagaki, F., 609 Hinrichs, K.-U., Teske, A., 2010. Acetogenesis in Deep Subseafloor Sediments of The Juan de 610 Fuca Ridge Flank: A Synthesis of Geochemical, Thermodynamic, and Gene-based Evidence. 611 Geomicrobiology Journal 27, 183-211.

612 Lin, L.-H., Slater, G.F., Sherwood Lollar, B., Lacrampe-Couloume, G., Onstott, T.C., 2005. The 613 yield and isotopic composition of radiolytic $\mathrm{H} 2$, a potential energy source for the deep 614 subsurface biosphere. Geochimica et Cosmochimica Acta 69, 893-903.

615 Lippmann, J., Stute, M., Torgersen, T., Moser, D.P., Hall, J.A., Lin, L., Borcsik, M., Bellamy, 616 R.E.S., Onstott, T.C., 2003. Dating ultra-deep mine waters with noble gases and 36Cl, 617 Witwatersrand Basin, South Africa. Geochimica et Cosmochimica Acta 67, 4597-4619.

618 Mast, A., Drever, J.I., 1987. The effect of oxalate on the dissolution rates of oligoclase and 619 tremolite. Geochimica et Cosmochimica Acta 51, 2559-2568.

620 McCollom, T.M., 2013. Laboratory Simulations of Abiotic Hydrocarbon Formation in Earth's 621 Deep Subsurface. Reviews in Mineralogy and Geochemistry 75, 467-494.

622 Ménez, B., 2020. Abiotic Hydrogen and Methane: Fuels for Life. Elements 16, 39-46.

623

624

625

626
Nealson, K.H., Inagaki, F., Takai, K., 2005. Hydrogen-driven subsurface lithoautotrophic microbial ecosystems (SLiMEs): do they exist and why should we care? Trends in Microbiology $13,405-410$.

Onstott, T.C., McGown, D.J., Bakermans, C., Ruskeeniemi, T., Ahonen, L., Telling, J., Soffientino, B., Pfiffner, S.M., Sherwood-Lollar, B., Frape, S., Stotler, R., Johnson, E.J., Vishnivetskaya, T.A., Rothmel, R., Pratt, L.M., 2009. Microbial Communities in Subpermafrost Saline Fracture Water at the Lupin Au Mine, Nunavut, Canada. Microbial Ecology 58, 786-807.

Pedersen, K., Ekendahl, S., 1992. Assimilation of CO2 and introduced organic compounds by bacterial communities in groundwater from southeastern Sweden deep crystalline bedrock. Microb Ecol 23, 1-14.

Pisapia, C., Gérard, E., Gérard, M., Lecourt, L., Lang, S.Q., Pelletier, B., Payri, C.E., Monnin, C., Guentas, L., Postec, A., Quéméneur, M., Erauso, G., Ménez, B., 2017. Mineralizing Filamentous Bacteria from the Prony Bay Hydrothermal Field Give New Insights into the Functioning of Serpentinization-Based Subseafloor Ecosystems. Frontiers in Microbiology 8.

Pizzarello, S., Garvie, L.A.J., 2014. Sutter's Mill dicarboxylic acids as possible tracers of parentbody alteration processes. Meteoritics \& Planetary Science 49, 2087-2094. 
Purkamo, L., Bomberg, M., Nyyssönen, M., Ahonen, L., Kukkonen, I., Itävaara, M., 2017.

640 Response of Deep Subsurface Microbial Community to Different Carbon Sources and Electron 641 Acceptors during 2 months Incubation in Microcosms. Frontiers in Microbiology 8.

642 Reeves, E.P., Fiebig, J., 2020. Abiotic Synthesis of Methane and Organic Compounds in Earth's 643 Lithosphere. Elements 16, 25-31.

644 Sahin, N., 2003. Oxalotrophic bacteria. Res. Microbiol. 154, 399-407.

645 Seewald, J.S., 2001. Aqueous geochemistry of low molecular weight hydrocarbons at elevated 646 temperatures and pressures: constraints from mineral buffered laboratory experiments. 647 Geochimica et Cosmochimica Acta 65, 1641-1664.

648 Sephton, M.A., Hazen, R.M., 2013. On the Origins of Deep Hydrocarbons. Reviews in 649 Mineralogy and Geochemistry 75, 449-465.

650 Sherwood Lollar, B., Heuer, V.B., McDermott, J., Tille, S., Warr, O., Moran, J.J., Telling, J., 651 Hinrichs, K.U., 2021. A window into the abiotic carbon cycle - Acetate and formate in fracture 652 waters in 2.7 billion year-old host rocks of the Canadian Shield. Geochimica et Cosmochimica 653 Acta 294, 295-314.

654 Sherwood Lollar, B., Onstott, T.C., Lacrampe-Couloume, G., Ballentine, C.J., 2014. The 655 contribution of the Precambrian continental lithosphere to global H2 production. Nature 516, $656 \quad 379-382$.

657 Streit, J., Tran-Ho, L.-C., Königsberger, E., 1998. Solubility of the Three Calcium Oxalate 658 Hydrates in Sodium Chloride Solutionsand Urine-Like Liquors. Monatshefte für Chemie / 659 Chemical Monthly 129, 1225-1236.

660 Tarnas, J.D., Mustard, J.F., Sherwood Lollar, B., Bramble, M.S., Cannon, K.M., Palumbo, A.M., 661 Plesa, A.C., 2018. Radiolytic H2 production on Noachian Mars: Implications for habitability and 662 atmospheric warming. Earth Planet. Sci. Lett. 502, 133-145.

663 Truche, L., Joubert, G., Dargent, M., Martz, P., Cathelineau, M., Rigaudier, T., Quirt, D., 2018. 664 Clay minerals trap hydrogen in the Earth's crust: Evidence from the Cigar Lake uranium deposit, 665 Athabasca. Earth Planet. Sci. Lett. 493, 186-197.

666 Truche, L., McCollom, T.M., Martinez, I., 2020. Hydrogen and Abiotic Hydrocarbons: 667 Molecules that Change the World. Elements 16, 13-18.

668 Waite, J.H., Glein, C.R., Perryman, R.S., Teolis, B.D., Magee, B.A., Miller, G., Grimes, J., 669 Perry, M.E., Miller, K.E., Bouquet, A., Lunine, J.I., Brockwell, T., Bolton, S.J., 2017. Cassini 670 finds molecular hydrogen in the Enceladus plume: Evidence for hydrothermal processes. Science $671356,155-159$.

672 Warr, O., Giunta, T., Ballentine, C.J., Sherwood Lollar, B., 2019. Mechanisms and rates of 4He, $67340 \mathrm{Ar}$, and $\mathrm{H} 2$ production and accumulation in fracture fluids in Precambrian Shield 674 environments. Chem. Geol. 530, 119322. 
675 Weiss, M.C., Sousa, F.L., Mrnjavac, N., Neukirchen, S., Roettger, M., Nelson-Sathi, S., Martin, 676 W.F., 2016. The physiology and habitat of the last universal common ancestor. Nature 677 Microbiology 1, 16116.

678 Zeng, Y., Liu, J., Zhu, Y., 2002. Short-chain carboxylates in high-temperature ore fluids of W-Sn 679 deposits in south China. GEOCHEMICAL JOURNAL 36, 219-234.

680 Ziegler, J.F., Ziegler, M.D., Biersack, J.P., 2010. SRIM The Stopping and Range of Ions in 681 Matter Nucl. Instrum. Methods Phys. Res., Sect. B 268, 1818-1823.

682 